Ömer Halisdemir Üniversitesi İktisadi ve İdari Bilimler Fakültesi Dergisi

Yul: 2022 Cilt-Sayı: 15(1) ss: 149-164

Academic Review of Economics and Administrative Sciences

Year: 2022 Vol-Issue: 15(1) pp: 149-164

http://dergipark.org/tr/pub/ohuiibf/

ISSN: 2564-6931

Araştırma Makalesi

Research Article

\title{
Monetary Policy Applicaton And Stock Market Reaction During Covid-19 PANDEMic: Evidence From TURKEY*
}

\author{
Özkan HAYKIR (I) \\ Özlem ÖZTÜRK-ÇETENAK ${ }^{\circledR 2}$
}

\begin{abstract}
This paper investigates whether the pandemic announcement and reducing policy rate of Turkey have an impact on the stock return, liquidity, and volatility of Borsa Istanbul. We employ event study methodology using 243 companies are listed on two main markets, namely BIST-Star and BIST-Main Markets, in Borsa Istanbul. The event dates are the pandemic announcement and three interest rates. We find that there is a negative reaction to the pandemic announcement and the announcement of the first decline in interest rates, but we discover a positive reaction to the second and third reduction in interest rates in terms of stock return and liquidity. Moreover, the stock return and liquidity of firms that are listed on the BIST-100 index and have associated derivatives are affected less by the pandemic. Results also suggest that the smallest, illiquid, volatile, and less Google-searched firms are affected more by the pandemic announcement and the first decline in the interest rate. The results suggest that the pandemic announcement increases the fear of the investors as well as the first decline in interest rates, but investors get used to the pandemic and react positively for the second and the third interest rate declines.
\end{abstract}

Key Words $\quad$ : COVID-19, Liquidity, Volatility, Google Search, Monetary Policy.

Jel Classification $\quad$ : G14, G15, E52.

\footnotetext{
* This paper is presented at the Seventh International Conference on Economics, April 9-11, 2021, organized by Turkish Economic Association.

${ }^{1}$ Dr. Öğr. Üyesi, Niğde Ömer Halisdemir Üniversitesi, İ.İ.B.F., Finans ve Bankacılık Bölümü, ozkanhaykir@gmail.com, ORCID: 0000-0003-2800-8699.

2 Doç. Dr., Niğde Ömer Halisdemir Üniversitesi, İ.İ.B.F., İktisat Bölümü, ozlemozturkcetenak@ohu.edu.tr, ORCID: 0000-0003-2014-0740.
}

Atif/Citation (APA6):

Haykır, Ö., \& Öztürk-Cetenak, Ö. (2022). Monetary policy application and stock market reaction during Covid-19 Pandemic: Evidence from Turkey. Ömer Halisdemir Üniversitesi İkisadi ve Idari Bilimler Fakültesi Dergisi, $15(1), 149-164$. http://doi.org/10.25287/ohuiibf.983443. 
Haykır, Ö., \& Öztürk-Çetenak, Ö. (2022). Monetary policy application and stock market reaction during Covid-19 Pandemic: Evidence from Turkey. Ömer Halisdemir Üniversitesi İktisadi ve İdari Bilimler Fakültesi Dergisi, 15(1), $149-164$.

\section{Covid-19 Pandemí Döneminde Para Politikasi

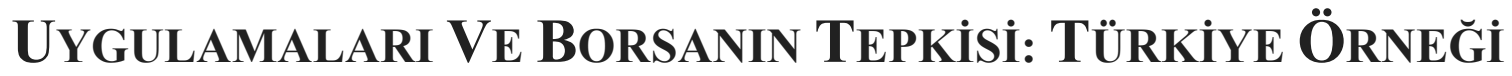

$\ddot{O} z$

Bu çalışma, pandemi duyurusu ve politika faizinin düşürülmesinin Borsa İstanbul'da yer alan hisse senetlerinin getirisi, likiditesi ve oynaklı̆̆ üzerindeki etkisini araştırmaktadır. Borsa İstanbul'da yer alan iki ana pazarda (BISSTYıldız ve BiST-Ana Piyasalar) işlem gören 243 şirket olay analizi metodolojisi ile incelenmiştir. Çalışmadaki olay tarihleri pandemi ilanı ve Merkez Bankasının yapmış olduğu üç faiz indirimi olarak belirlenmiştir. Pandemi duyurusuna ve faiz oranlarındaki ilk indirimin hisse senedi getirisi ve likiditesi açısından olumsuz bir etkisi olmasına rağmen, faiz oranlarındaki ikinci ve üçüncü indirim ise hisse senedi getirisi ve likiditesini olumlu bir şekilde etkilemişstir. Ayrıca, BIST-100 endeksinde yer alan ve türev piyasasinda işlem gören firmaların hisse senedi getirisi ve likiditesi pandemi ilanindan daha az etkilenmiştir. Sonuçlar ayrica en küçük, likit olmayan, oynakliğl yüksek ve Google'da daha az aranan firmaların pandemi duyurusundan ve faiz oranındaki ilk düşüşten daha fazla etkilendiğini göstermiştir. Çalışma, pandemi duyurusunun ve faiz oranlarındaki ilk indirimin yatırımcıların korkusunu artırdı̆̆ını, ancak yatırımcıların pandemiye giderek alıştığını ve ikinci ve üçüncü faiz indirimlerine olumlu tepki verdiğini göstermistir.

Anahtar Kelimeler $\quad$ : COVID-19, Likidite, Volatilite, Google Arama, Para Politikast.

Jel Sinıflandirmast $\quad:$ G14, G15, E52.

\section{INTRODUCTION}

On December 31, the authority in Wuhan, China confirmed the first COVID-19 case. After a short period, the virus has spread all over the world, and the World Health Organization (WHO) had to declare COVID-19 as a pandemic on March 11, 2020 (WHO, 2020) and after this date, countries have taken the necessary precautionary actions rapidly. Due to the pandemic, most of the companies around the world shut down their operations for a while and had to endure huge losses of income, which in turn had a devastating impact on the economies of most of the countries as well as the stock markets. As a first response to the pandemic, central banks of some countries bought treasury bills or lowered the interest rates to provide liquidity to the real economy and slow down the meltdown. For instance, "FED pumps in more than $\$ 1$ trillion in the dramatic ramping up of market intervention amid coronavirus meltdowns" (CNCB, 2020).

This paper aims to investigate the impact of the COVID-19 pandemic announcement and subsequent declines in interest rate by the Central Bank of the Republic of Turkey on the return, liquidity, and volatility of the Turkish stock market. There are several reasons to choose Turkey. First, Turkey is one of the most affected countries by the pandemic in terms of the number of cases, it is ranked in seventh place (Worldometers, 2020). Second, the stock market of Turkey has declined around 27 percent during the pandemic (see Table 1) which is one of the highest among the emerging markets.

Table 1: Change in Stock Market Indices during COVID-19

\begin{tabular}{lllll}
\hline \multicolumn{5}{c}{ Index Value } \\
\hline Index & Country & 21.01 .2020 & 31.03 .2020 & Difference (\%) \\
\hline Shangai & China & 3052.14 & 2750.3 & $-9.89 \%$ \\
JSE & South Africa & 51835.36 & 40738.57 & $-18.19 \%$ \\
IPC & Mexico & 45637.32 & 34554.53 & $-24.28 \%$ \\
BIST 100 & Turkey & 1235.56 & 896.44 & $-27.45 \%$ \\
Bovespa & Brazil & 117026.04 & 73019.76 & $-37.60 \%$ \\
\hline
\end{tabular}

Source: Investing, 2020. 
Haykır, Ö., \& Öztürk-Çetenak, Ö. (2022). Monetary policy application and stock market reaction during Covid-19 Pandemic: Evidence from Turkey. Ömer Halisdemir Üniversitesi İktisadi ve İdari Bilimler Fakültesi Dergisi, 15(1), $149-164$.

Since the immediate impact of crises in the financial markets obliges the Central Banks to take precautionary measures quickly. The Central Banks can use two types of monetary policy tools, namely direct and indirect monetary policy tools to minimize the negative effect of the crises. While direct monetary policy instruments affect the interest rate or loan deposits, indirect policy instruments interact according to the amount of supply and demand in the market (Alexander et al., 1995).

Changes in the money supply cause the investor to revalue the stock market. The announcement of a monetary policy change affects the stock price by changing the net present value of the investment and the expected future return (Herwany et al., 2017). Monetary policy changes may affect stock prices through two different channels, such as bank loans and interest rates. Tight monetary policy practices lead to a contraction in the credit volume of banks (Bernanke \& Blinder, 1990). A decrease in bank loans causes the cost of capital to rise, dividend distribution decreases and eventually stock prices fall. In addition, monetary policy can change the returns and prices of financial assets such as bonds, thereby changing the demand for stocks and in this way the stock prices (Scharler, 2008).

The paper contributes to the literature in numerous ways. First, we examine the impact of the reduction in the interest rates during COVID-19 on the stock market. Second, we have not only focused on the stock return but also have analyzed the stock liquidity and volatility as a response to a cut in the interest rates. Third, we compare the return, liquidity, and volatility in sub-groups: first, whether the securities are listed on the BIST-100 index and whether they have associated derivatives. Finally, to capture the investor sentiment during the pandemic, daily Google search data of each company have obtained and its impact on stock returns is analyzed.

The remainder of this study is as follows: Section 2 summarizes the prior literature. Section 3 presents data and methodology. Section 4 shows the empirical results. Section 5 concludes the study.

\section{I.LITERATURE REVIEW}

The Covid-19 outbreak, which emerged in China in December 2019, rapidly spread to other countries around the world, and millions of people were affected by the pandemic. As of 14 October 2020, there are over 38 million confirmed cases and more than a million people died due to COVID-19 worldwide. Although there has not been a global pandemic since the Spanish flu in 1918-1919, various regional pandemics have occurred in the past 100 years such as Asian flu (1957), Hong Kong flu (1968), SARS (2002), MERS (2012) and EBOLA (2013-2016). 40 million people died worldwide from the Spanish flu. The cost of the Spanish flu was more than four trillion dollars. In the SARS pandemic, 900 people died and according to the World Bank, the cost of SARS to the global economy was 54 billion dollars. The Ebola outbreak resulted in 11,300 human deaths in West Africa and 53 billion dollars in economic losses (Fernandez, 2020).

Most of the industries are adversely affected by the COVID-19 pandemic. Studies show that the tourism sector is the one that is mostly affected since strict measures taken by countries reduce the occupancy rates of hotels by stopping the entry of domestic and foreign tourists. Thus, it becomes difficult for tourism companies to manage their costs. These negative demand shocks that many sectors also experience causes fluctuations in stock markets as well (Kandil Göker et al., 2020).

Even though numerous papers investigate the economic impact of the COVID-19 pandemic, it is still not clear today. Although there are dramatic changes in macroeconomic indicators around the world, it is difficult to know the consequences of an ongoing pandemic. However, the experience gained from previous pandemics shows that the pandemics affect the production behavior of companies and the consumption 
Haykır, Ö., \& Öztürk-Çetenak, Ö. (2022). Monetary policy application and stock market reaction during Covid-19 Pandemic: Evidence from Turkey. Ömer Halisdemir Üniversitesi İktisadi ve İdari Bilimler Fakültesi Dergisi, 15(1), $149-164$.

behavior of individuals as well as the financial markets. These developments are also reflected in national and global economic indicators.

Pandemics have a devastating influence on individuals since the lockdown decisions taken by governments during pandemics keep people away from their jobs and consumption. Individuals whose wages are not paid or who are worried that they will not be paid in the future feel financially under pressure and reduce their expenditures. On the other hand, manufacturers suspend production to observe the new purchasing behavior of consumers and firms. The decrease in cash flows brings about bankruptcies (Baldvin \& Mauro, 2020).

Governments are taking various actions to mitigate the negative effects of the pandemic on the economy. Although different practices are observed in different countries, roughly these measures can be grouped under 3 folds. The first of these is to make support payments to people who are locked up and unable to work, the second is to ensure that vital sectors continue their activities (such as food), and the third is to take necessary measures to prevent imbalances that may arise in the markets. These measures were also implemented in Turkey during the Covid-19 period.

Since the beginning of the COVID-19 pandemic, governments and central banks have been implementing a wide variety of economic policies to eliminate the negative effects and risks caused by the pandemic (Elgin et al., 2020; Nicola et al., 2020; Carlsson-Szlezak et al., 2020). Investment in stock markets includes country risks for foreign investors (Dooley \& Hutchison, 2009; Yang et al., 2018). Such risks are especially higher for developing countries (Hibbert \& Pavlova, 2017). However, at the beginning of the pandemic, there has been a remarkable increase in the risk level of all countries regardless of developed or developing (Zhang et al., 2020; Kartal, 2020; Gormsen \& Koijen, 2020). Hence, both domestic and foreign investors tend to buy or hold more liquid assets. This change in the behavior of investors has an impact on the stock market indices of countries (Bekaert \&Harvey, 1995; Gumus, 2010).

As a first response to the announcement of the pandemic, the stock markets around the world have declined. (Al-Awadhi et al., 2020; Ahmar and del Val, 2020; Yan, 2020). Preliminary studies have shown that there is a negative relationship between the number of COVID-19 cases and deaths and financial markets (Alber, 2020; Zeren \& Hizarci, 2020; Sansa 2020; Senol \& Zeren, 2020). The impacts of the Covid19 outbreak on stock markets are much greater than earlier pandemics. For example, although there were higher deaths in the Spanish flu, the US stock markets have not been affected as much as the pandemic in 2020. For this reason, it is emphasized that fluctuations in stock markets cannot be explained solely with the number of deaths, locking practices, travel restrictions and mandatory social distance practices should also be taken into account. The economic consequences of such practices will certainly be severe. However, governments had to choose between a collapse in the health system and an economic contraction (Baker et al., 2020).

The decline in the Chinese stock market at the end of January 2020 because of the pandemic has spread to other financial markets in the first quarter of 2020. The negative impact of the pandemic, especially on developing stock markets, continues until mid-April. Studies show that the financial markets remain strong and relatively stable in China, which is the starting point of the pandemic and the country that survived the pandemic process the hardest (Xinhua, 2020). While the pandemic affected emerging Asian markets the most, European markets were less affected. The response time of governments and the size of the incentive packages they announce are also important in balancing the effects of the pandemic on financial markets (Topcu \& Gulal, 2020). The different measures are taken in each country end up with different outcomes (Contessi \& Pace, 2020). It has been observed that the increase in volatility in stock markets due to the pandemic is lower in countries with high public trust in the government, and higher in countries with low confidence (Engelhardt et al., 2021). It is thought that this volatility increase due to the 
Haykır, Ö., \& Öztürk-Çetenak, Ö. (2022). Monetary policy application and stock market reaction during Covid-19 Pandemic: Evidence from Turkey. Ömer Halisdemir Üniversitesi İktisadi ve İdari Bilimler Fakültesi Dergisi, 15(1), $149-164$.

pandemic may become permanent even if the uncertainty in global economic policies disappears (Bai et al., 2020).

There have not been many studies investigating the effect of the pandemic on stock markets, and existing studies generally examine the link between the number of cases or deaths and stock return during a pandemic (Topcu \& Gulal, 2020; Ashraf, 2020; Khan et al., 2020). Baker et al. (2020) uses a text-based method and capture the impact of the pandemic on the stock market. The closest study has been done by Rahman et al. (2020) who study the effect of government stimulus packages on stock return.

\section{II.DATA AND METHODOLOGY}

Our data comprises 243 companies that are listed in the two main markets, namely BIST-Star and BIST-Main Markets, in Borsa Istanbul. The companies must have at least 50 million Turkish Lira (TRY) market capitalization to be listed on these two markets which cover most of the trading in Borsa Istanbul. These two markets cover almost 90 percent of trading volume in Borsa Istanbul based on the calculation using the daily bulletin of Borsa Istanbul.

We use several databases to collect our data. Firstly, we use Compustat Global Database to obtain a daily return, trading value, and share outstanding. Secondly, we use investing.com to download our control variables, namely iShares MSCI Turkey ETF, 5-years CDS, and Dollar-TRY exchange rate. Third, we use the Google trend website to retrieve Google search data for each company.

We focus on two main events regarding the COVID-19 pandemic. The first event is the announcement that COVID-19 is a global pandemic by the WHO. Surprisingly, it coincides with the first case in Turkey as well, 11 March 2020. The second main event is the Central Bank of the Republic of Turkey cuts the interest rate, which happened three times after the pandemic announcement (17 March 2020 from 10.75 to 9.75 percent, 24 April 2020, from 9.75 to 8.75 percent, 21 May 2020 from 8.75 to 8.25 percent).

Several methods can be used to determine the abnormal return in event study methodologies such as historical mean return, index return, or market model. As a return-generating process, we apply the historical average methods (Schweitzer, 1989). This model assumes that the expected return of a company should be similar to its historical mean return and if it is not the same, the deviation can be considered as an abnormal return. Brown and Warner (1980 \& 1985) show that the historical mean return model generally generates similar results as other models since the variance of abnormal returns is not reduced much by using other models.

The abnormal return of each stock is calculated as follows:

$$
A R_{i t}=\text { Return }_{i t}-\overline{\operatorname{Return}_{l, t-150 \text { to } t-30}}
$$

where $A R_{i t}$ refers to an abnormal return of a stock.

The historical mean return of an individual stock is calculated 150 days to 30 days before the actual event date. This period is called the estimation window. The estimation window is designed based on our first event date. We compute cumulative abnormal return (CAR) around several event windows [-2 / +2], [$5 /+5]$ and $[-7 /+7]$ to capture the immediate and late reaction of stock market. CAR is calculated as the sum of abnormal returns during the three event windows separately. We follow Rahman et al. (2020) and restrict our event window up to seven days to eliminate the impact of other events. As a statistical significance test, we adopt a cross-sectional t-test. 
Haykır, Ö., \& Öztürk-Çetenak, Ö. (2022). Monetary policy application and stock market reaction during Covid-19 Pandemic: Evidence from Turkey. Ömer Halisdemir Üniversitesi İktisadi ve İdari Bilimler Fakültesi Dergisi, 15(1), $149-164$.

We extend our study and examine the stock liquidity and volatility around our event days as well. To analyze liquidity, we use Amihud (2002) measure which is the most widely used liquidity proxy in finance literature ${ }^{4}$. It is calculated as an absolute return divided by trading value for each day. Volatility is calculated as a standard deviation of the past 30 days' return. We adopt the same approach we use for return and compute cumulative abnormal liquidity (CAL) and volatility (CAV) based on liquidity (volatility) minus historical average liquidity (volatility).

\section{EMPIRICAL RESULTS}

Table 2 presents pre, post, and difference of average CAR, CAL, and CAV for different events and estimation window periods. Panel A shows the results on the effect of the WHO pandemic announcement on the stock market. At first glance, there is a negative and strong impact of the pandemic announcement on all three variables in all event windows. The average CAR declines by almost 36 percent after the announcement if we look at seven days event window. Similarly, liquidity has also dramatically declined after the announcement, and volatility increases in all event windows. This can be interpreted as the reaction of the investors at the point where the uncertainty is maximum, and they sell their stocks in order not to suffer further losses.

Panel B shows the first decline in interest rate to pump liquidity into the stock markets to slow down the meltdown in the stock market. In a two-day window, lowering the interest rate has no significant impact on CAR, CAL, or CAV. This can be interpreted as lowering interest rates helps to slow down the bad impact of the pandemic. However, in the longer periods, the immediate positive impact is gone away, and the CAR becomes negative and statistically significant. CAL shows that liquidity is lower, and CAV is positive and statistically significant in longer event windows. Since the day of the first decline in interest rate is very close to the pandemic announcement and the first COVID-19 case in Turkey, it does not have a strong positive impact on the stock market due to uncertainty in the future.

The positive impact of lowering the interest rate can be seen in Panel C. In all event windows, the CAR is positive which suggests that the second interest rate decline helps to recover the return of the stocks. The increase in CAR is not as strong as the decline in the first two events, but it is positive and statistically significant. Similarly, a positive impact can be seen in the liquidity proxy. Liquidity increases by approximately six percent (longer event window). Interestingly, the volatility is still positive and statistically significant. In other words, volatility is still increasing. There may be two explanations for this. Either the uncertainty of the future due to the pandemic still causes the fluctuation in stock markets or unprofessional investors who would like to benefit from the low level of stock price to begin trading on the stock market. During the pandemic, the number of small investors increases dramatically in the Turkish stock market (Central Securities Depository of the Turkish Capital Markets, 2020).

Lastly, Panel D presents the results of the third decline in the interest rate. The results are similar to Panel $\mathrm{C}$ in that average CAR and CAL are positive and statistically significant, particularly longer event windows. Volatility is still positive and significant for all event windows. Overall, the average CAR, CAL, and CAV are generally statistically insignificant for a short event window [-2 +2]. Rahman et al. (2020) state that investors underreact to some events and they need some time to evaluate the impact of the event and respond accordingly. Thus, this may cause the market to adjust itself to this new information in longer event windows.

\footnotetext{
${ }^{4}$ Amihud (2002) interpreted as illiquidity. In other words, increase in the Amihud variable refers to decline in liquidity of stocks.
} 
Haykır, Ö., \& Öztürk-Çetenak, Ö. (2022). Monetary policy application and stock market reaction during Covid-19 Pandemic: Evidence from Turkey. Ömer Halisdemir Üniversitesi İktisadi ve İdari Bilimler Fakültesi Dergisi, 15(1), $149-164$.

Table 2: Event Study: Average CAR, CAL, and CAV

\begin{tabular}{|c|c|c|c|c|c|c|c|c|c|}
\hline \multicolumn{10}{|c|}{ PANEL A: WHO Pandemic Announcement (11 March 2020) } \\
\hline \multirow{2}{*}{ Variables } & \multicolumn{3}{|c|}{$-2 /+2$} & \multicolumn{3}{|l|}{$-5 /+5$} & \multicolumn{3}{|l|}{$-7 /+7$} \\
\hline & Pre & Post & Diff & Pre & Post & Diff & Pre & Post & Diff \\
\hline Return & -0.115 & -0.282 & $\begin{array}{l}-0.166^{* *} \\
(0.04)\end{array}$ & -0.088 & -0.405 & $\begin{array}{l}-0.316^{* * * *} \\
(0.000)\end{array}$ & -0.005 & -0.364 & $\begin{array}{l}-0.359 * * * \\
(0.000)\end{array}$ \\
\hline Liquidity & 0.018 & 0.067 & $\begin{array}{l}0.048 * * \\
(0.014)\end{array}$ & 0.008 & 0.162 & $\begin{array}{l}0.154 * * * \\
(0.001)\end{array}$ & 0.012 & 0.192 & $\begin{array}{l}0.180 * * * \\
(0.000)\end{array}$ \\
\hline Volatility & 0.018 & 0.070 & $\begin{array}{l}0.051^{*} \\
(0.054)\end{array}$ & 0.034 & 0.141 & $\begin{array}{l}0.108^{* * *} \\
(0.000)\end{array}$ & 0.044 & 0.187 & $\begin{array}{l}0.143 * * * \\
(0.000)\end{array}$ \\
\hline \multicolumn{10}{|c|}{ PANEL B: First Decline on Interest Rate (17 March 2020) } \\
\hline Return & -0.013 & -0.132 & $\begin{array}{l}-0.119 \\
(0.124)\end{array}$ & -0.163 & -0.329 & \multirow{3}{*}{$\begin{array}{l}-0.166^{* * *} \\
(0.004) \\
0.166^{* * *} \\
(0.001) \\
0.141^{* * *} \\
(0.003)\end{array}$} & -0.219 & -0.415 & \multirow{3}{*}{$\begin{array}{l}-0.196^{* * * *} \\
(0.003) \\
0.195 * * * \\
(0000) \\
0.184^{* * *} \\
(0.000)\end{array}$} \\
\hline Liquidity & 0.041 & 0.109 & $\begin{array}{l}0.067 \\
(0.159)\end{array}$ & 0.066 & 0.232 & & 0.068 & 0.264 & \\
\hline Volatility & 0.032 & 0.103 & $\begin{array}{l}0.070^{*} \\
(0.051)\end{array}$ & 0.052 & 0.193 & & 0.059 & 0.243 & \\
\hline \multicolumn{10}{|c|}{ PANEL C: Second Decline on Interest Rate (24 April 2020) } \\
\hline Return & 0.001 & 0.049 & $\begin{array}{l}0.049 * * * \\
(0.001)\end{array}$ & 0.030 & 0.087 & \multirow{3}{*}{$\begin{array}{l}0.057 * * * \\
(0.000) \\
-0.036 * * * \\
(0.000) \\
0.124 * * * \\
(0.001) \\
\end{array}$} & 0.012 & 0.069 & \multirow{3}{*}{$\begin{array}{l}0.057 * * * \\
(0.000) \\
-0.046^{* * *} \\
(0.000) \\
0.167 * * * \\
(0.000) \\
\end{array}$} \\
\hline Liquidity & -0.008 & -0.022 & $\begin{array}{l}-0.014^{*} \\
(0.06)\end{array}$ & -0.014 & -0.050 & & -0.016 & -0.062 & \\
\hline Volatility & 0.041 & 0.103 & $\begin{array}{l}0.062 * \\
(0.059)\end{array}$ & 0.088 & 0.212 & & 0.118 & 0.286 & \\
\hline \multicolumn{10}{|c|}{ PANEL D: Third Decline on Interest Rate (21 May 2020) } \\
\hline Return & 0.018 & 0.023 & $\begin{array}{l}0.005 \\
(0.554)\end{array}$ & 0.011 & 0.023 & $\begin{array}{l}0.011 \\
(0.131)\end{array}$ & 0.028 & 0.046 & \multirow{3}{*}{$\begin{array}{l}0.019 * * \\
(0.011) \\
-0.059 * * * \\
(0.000) \\
0.066 * * * \\
(0.000)\end{array}$} \\
\hline Liquidity & -0.008 & -0.026 & $\begin{array}{l}-0.018^{*} \\
(0.051)\end{array}$ & -0.022 & -0.067 & $\begin{array}{l}-0.045^{* * *} \\
(0.000)\end{array}$ & -0.028 & -0.088 & \\
\hline Volatility & 0.013 & 0.038 & $\begin{array}{l}0.025^{*} \\
(0.053)\end{array}$ & 0.027 & 0.077 & $\begin{array}{l}0.049 * * * \\
(0.001)\end{array}$ & 0.039 & 0.105 & \\
\hline
\end{tabular}

Notes: The table reports the average cumulative abnormal return, liquidity, and volatility for different event windows and different events. We adopt the historical mean methodology to compute the cumulative abnormal return, liquidity, and volatility. The historical mean return, liquidity, and volatility of an individual stock are calculated 150 days to 30 days before the actual event date. We use the announcement of the pandemic by WHO and decrease the interest rate by the Central Bank of Turkey during the pandemic as events. The statistical significance of variables is tested using the cross-sectional t-test. P-values are in the parenthesis. ${ }^{*}, * * * * *$ show the statistical significance at the 10,5 , and 1 percent levels, respectively.

As a second analysis, we have grouped the companies based on two factors: whether or not the firms are listed on the BIST-100 index and whether or not they have associated derivatives. Several studies show that there is a positive and significant impact on stock return when the stock is included in the primary index (Shleifer, 1986; Jain, 1987; Kasch \& Sarkar, 2011). Besides, having associated derivatives cause a higher return (Conrad, 1989; Detemple \& Jorion, 1990; Sorescu, 2000). Table 3 reveals the results of these subgroups. The results show that the effect is less for BIST-100 stocks compare to the outside of BIST-100 companies in all events. 
Haykır, Ö., \& Öztürk-Çetenak, Ö. (2022). Monetary policy application and stock market reaction during Covid-19 Pandemic: Evidence from Turkey. Ömer Halisdemir Üniversitesi İktisadi ve İdari Bilimler Fakültesi Dergisi, 15(1), $149-164$.

Table 3: Comparison between the BIST-100 or not and have associated derivative or not.

\begin{tabular}{|c|c|c|c|c|c|c|c|c|}
\hline \multicolumn{9}{|c|}{ PANEL A: WHO Pandemic Announcement (11 March 2020) } \\
\hline Variables & & $-2 /+2$ & $-5 /+5$ & $-7 /+7$ & & $-2 /+2$ & $-5 /+5$ & $-7 /+7$ \\
\hline \multirow{2}{*}{ Return } & Bist-100 & $\begin{array}{l}-0.110^{*} \\
(0.053)\end{array}$ & $\begin{array}{l}-0.244 * * * \\
(0.000)\end{array}$ & $\begin{array}{l}-0.280 * * * \\
(0.000)\end{array}$ & Derivatives & $\begin{array}{l}-0.088^{*} \\
(0.058)\end{array}$ & $\begin{array}{l}-0.195 * * * \\
(0.000)\end{array}$ & $\begin{array}{l}-0.222 * * * \\
(0.000)\end{array}$ \\
\hline & Not Bist-100 & $\begin{array}{l}-0.202 * * \\
(0.035)\end{array}$ & $\begin{array}{l}-0.364 * * * \\
(0.000)\end{array}$ & $\begin{array}{l}-0.411 * * * \\
(0.000)\end{array}$ & Not Derivatives & $\begin{array}{l}-0.123^{*} \\
(0.053)\end{array}$ & $\begin{array}{l}-0.272 * * * \\
(0.000)\end{array}$ & $\begin{array}{l}-0.313^{* * *} \\
(0.000)\end{array}$ \\
\hline \multirow{4}{*}{ Liquidity } & Bist-100 & $0.007 * *$ & $0.017 * * *$ & $0.020 * * *$ & Derivatives & $0.001 * *$ & $0.002 * * *$ & $0.003 * * *$ \\
\hline & & $(0.024)$ & $(0.001)$ & $(0.000)$ & & $(0.037)$ & $(0.000)$ & $(0.000)$ \\
\hline & Not Bist-100 & $0.082 * *$ & $0.229 * * *$ & $0.269 * * *$ & Not Derivatives & $0.011 * *$ & $0.025 * * *$ & $0.030 * * *$ \\
\hline & & $(0.022)$ & $(0.000)$ & $(0.000)$ & & $(0.023)$ & $(0.000)$ & $(0.000)$ \\
\hline \multirow{3}{*}{ Volatility } & & $0.032 *$ & $0.065 * * *$ & $0.087 * * *$ & Derivatives & $0.031^{*}$ & $0.064 * * *$ & $0.085 * * *$ \\
\hline & Not Bist-100 & $0.057^{*}$ & $0.119^{* * *}$ & $0.157 * * *$ & Not Derivatives & $0.033^{*}$ & $0.067 * * *$ & $0.088 * * *$ \\
\hline & & $(0.054)$ & $(0.000)$ & $(0.000)$ & & $(0.056)$ & $(0.000)$ & $(0.000)$ \\
\hline \multicolumn{9}{|c|}{ PANEL B: First Decline on Interest Rate (17 March 2020) } \\
\hline \multirow{2}{*}{ Return } & Bist-100 & $\begin{array}{l}-0.102 \\
(0.154)\end{array}$ & $\begin{array}{l}-0.137 * * * \\
(0.003)\end{array}$ & $\begin{array}{l}-0.159^{* * *} \\
(0.002)\end{array}$ & Derivatives & $\begin{array}{l}-0.084 \\
(0.180)\end{array}$ & $\begin{array}{l}-0.115^{* * *} \\
(0.003)\end{array}$ & $\begin{array}{l}-0.134 * * * \\
(0.001)\end{array}$ \\
\hline & Not Bist-100 & $\begin{array}{l}-0.131 \\
(0.109)\end{array}$ & $\begin{array}{l}-0.186^{* * *} \\
(0.004)\end{array}$ & $\begin{array}{l}-0.222 * * * \\
(0.003)\end{array}$ & Not Derivatives & $\begin{array}{l}-0.113 \\
(0.143)\end{array}$ & $\begin{array}{l}-0.149^{* * *} \\
(0.003)\end{array}$ & $\begin{array}{l}-0.173 * * * \\
(0.002)\end{array}$ \\
\hline \multirow{4}{*}{ Liquidity } & Bist-100 & 0.009 & $0.018^{* * *}$ & $0.022 * * *$ & Derivatives & 0.001 & $0.003 * * *$ & $0.003 * * *$ \\
\hline & & $(0.186)$ & $(0.001)$ & $(0.000)$ & & $(0.172)$ & $(0.001)$ & $(0.000)$ \\
\hline & Not Bist-100 & 0.109 & $0.251 * * *$ & $0.293 * * *$ & Not Derivatives & 0.014 & $0.026^{* * *}$ & $0.032 * * *$ \\
\hline & & $(0.155)$ & $(0.000)$ & $(0.000)$ & & $(0.186)$ & $(0.001)$ & $(0.000)$ \\
\hline \multirow{4}{*}{ Volatility } & Bist-100 & $0.051^{*}$ & $0.100 * * *$ & $0.131 * * *$ & Derivatives & $0.047^{*}$ & $0.091^{* * *}$ & $0.120^{* * *}$ \\
\hline & & $(0.051)$ & $(0.000)$ & $(0.000)$ & & $(0.052)$ & $(0.000)$ & $(0.000)$ \\
\hline & Not Bist-100 & $0.075^{*}$ & $0.151^{* * *}$ & $0.198 * * *$ & Not Derivatives & $0.054 *$ & $0.105^{* * *}$ & $0.137 * * *$ \\
\hline & & $(0.051)$ & $(0.000)$ & $(0.000)$ & & $(0.051)$ & $(0.000)$ & $(0.000)$ \\
\hline \multicolumn{9}{|c|}{ PANEL C: Second Decline on Interest Rate (24 April 2020) } \\
\hline \multirow{4}{*}{ Return } & Bist-100 & $0.045^{* *}$ & $0.049^{* * *}$ & $0.045^{* * *}$ & Derivatives & $0.024 *$ & $0.016^{* *}$ & 0.009 \\
\hline & & $(0.020)$ & $(0.000)$ & $(0.001)$ & & $(0.054)$ & $(0.030)$ & $(0.168)$ \\
\hline & Not Bist-100 & $0.051 * *$ & $0.062 * * *$ & $0.062 * * *$ & Not Derivatives & $0.058 * *$ & $0.069 * * *$ & $0.068^{* * *}$ \\
\hline & & $(0.011)$ & $(0.001)$ & $(0.000)$ & & $(0.017)$ & $(0.000)$ & $(0.000)$ \\
\hline \multirow{3}{*}{ Liquidity } & Bist-100 & $-0.002^{*}$ & $-0.003 * * *$ & $-0.004 * * *$ & Derivatives & $-0.001^{*}$ & $-0.001 * * *$ & $-0.001^{* * *}$ \\
\hline & Not Bist-100 & $(0.063)$ & $(0.000)$ & $(0.000)$ & & $(0.076)$ & $\begin{array}{l}(0.000) \\
0.005 * * *\end{array}$ & $\begin{array}{l}(0.000) \\
-0.006 * * *\end{array}$ \\
\hline & HOL DIST-IOU & $(0.063)$ & $(0.000)$ & $(0.000)$ & Not Derivatives & $(0.062)$ & $(0.000)$ & $(0.000)$ \\
\hline \multirow{3}{*}{ Volatility } & Bist-100 & $\begin{array}{l}0.054^{*} \\
(0.054)\end{array}$ & $\begin{array}{l}0.109 * * * \\
(0.000)\end{array}$ & $\begin{array}{l}0.146^{* * * *} \\
(0.000)\end{array}$ & Derivatives & $\begin{array}{l}0.054^{*} \\
(0.052)\end{array}$ & $\begin{array}{l}0.108^{* * * *} \\
(0.000)\end{array}$ & $\begin{array}{l}0.143 * * * \\
(0.000)\end{array}$ \\
\hline & Not Bist-100 & $0.060^{*}$ & $0.121 * * *$ & $0.164 * * *$ & Not Derivatives & $0.054 *$ & $0.109 * * *$ & $0.147 * * *$ \\
\hline & & $(0.062)$ & $(0.001)$ & $(0.000)$ & & $(0.055)$ & $(0.000)$ & $(0.000)$ \\
\hline \multicolumn{9}{|c|}{ PANEL D: Third Decline on Interest Rate (21 May 2020) } \\
\hline \multirow{4}{*}{ Return } & Bist-100 & 0.008 & $0.020 * *$ & $0.029 * * *$ & Derivatives & 0.010 & $0.028^{* * *}$ & $0.037 * * *$ \\
\hline & & $(0.405)$ & $(0.011)$ & $(0.001)$ & & $(0.384)$ & $(0.003)$ & $(0.000)$ \\
\hline & Not Bist-100 & 0.002 & 0.005 & 0.011 & Not Derivatives & 0.007 & $0.015^{*}$ & $0.024 * * *$ \\
\hline & & $(0.751)$ & $(0.505)$ & $(0.112)$ & & $(0.458)$ & $(0.050)$ & $(0.004)$ \\
\hline \multirow{4}{*}{ Liquidity } & Bist-100 & $-0.002 *$ & $-0.005 * * *$ & $-0.006 * * *$ & Derivatives & $-0.001 * *$ & $-0.001 * * *$ & $-0.001 * * *$ \\
\hline & & $(0.053)$ & $(0.001)$ & $(0.000)$ & & $(0.027)$ & $(0.001)$ & $(0.000)$ \\
\hline & Not Bist-100 & $-0.028^{*}$ & $-0.072 * * *$ & $-0.097 * * *$ & Not Derivatives & $-0.004^{*}$ & $-0.007 * * *$ & $-0.009 * * *$ \\
\hline & & $(0.052)$ & $(0.000)$ & $(0.000)$ & & $(0.056)$ & $(0.000)$ & $(0.000)$ \\
\hline \multirow{3}{*}{ Volatility } & Bist-100 & $0.018 *$ & $0.036^{* * *}$ & $0.048 * * *$ & Derivatives & $0.015^{*}$ & $0.030^{* * *}$ & $0.041 * * *$ \\
\hline & Not Bist-100 & $\begin{array}{l}(0.054) \\
0.023 *\end{array}$ & $\begin{array}{l}(0.000) \\
0.047 * * *\end{array}$ & $\begin{array}{l}(0.000) \\
0.064 * * *\end{array}$ & Not Derivatives & $\begin{array}{l}(0.060) \\
0.020 *\end{array}$ & $\begin{array}{l}(0.000) \\
0.040 * * *\end{array}$ & $\begin{array}{l}(0.000) \\
0.054 * * *\end{array}$ \\
\hline & & $(0.053)$ & $(0.000)$ & $(0.000)$ & & $(0.052)$ & $(0.000)$ & $(0.000)$ \\
\hline
\end{tabular}

Notes: The table reports the average cumulative abnormal return, liquidity, and volatility for different event windows and different events. First, we group the companies based on whether they are listed in BIST-100 index or not, and second, we group the companies based on whether they have associated derivatives or not. For the second analysis, there are around 30 companies that have associated derivatives in Turkish stock markets; therefore, we restrict our sample to the companies are listed on BIST-100 index. Thus, there are around 30 companies in the derivatives group and 70 companies in the not derivatives group. The statistical significance of variables is tested using the cross-sectional t-test. P-values are in the parenthesis. $*, * *, * * *$ show the statistical significance at the 10,5 , and 1 percent levels, respectively. 
Haykır, Ö., \& Öztürk-Çetenak, Ö. (2022). Monetary policy application and stock market reaction during Covid-19 Pandemic: Evidence from Turkey. Ömer Halisdemir Üniversitesi İktisadi ve İdari Bilimler Fakültesi Dergisi, 15(1), $149-164$.

Further, we investigate the influence of firm characteristics on average CAR using sorting analysis. We sort the stocks into quintile portfolios based on size, liquidity, volatility as a firm characteristic's proxies, and Google trend data to capture the investor sentiment and compute the average CAR for each portfolio. In each portfolio, we have around 50 firms. There is a vast literature that Google search is one of the best proxies for investor sentiment (Da et al., 2011; Bank et al., 2011; Vlastiakis \& Markellos, 2012; Han et al., 2018; Huang et al., 2020). We use the ticker symbol of each firm during our sample period to obtain Google trend data.

Table 4 presents the results of the first and last portfolios for brevity. The findings show that in the first two events the average CAR is negative and statistically significant for most of the event windows and in the last two events the average CAR is positive and statistically significant. Results support our earlier findings. It is found that the smallest and illiquid firms are affected more by all events, the average CAR is almost twice higher than the largest and liquid firms. In other words, small, illiquid, and volatile firms are exposed to the COVID-19 pandemic more. Similarly, a low google search portfolio has a negative and higher average CAR compared to a high Google search portfolio, but the difference is not as high as other firm-characteristics sorted portfolios. In the last two events, the results are mixed for size, volatility, and Google trend sorted portfolios. However, liquidity sorted portfolios show that the illiquid portfolio earns more average CAR compared to liquid firms around the last two events.

After the sorting analysis, we finalize our empirical part by running a regression using $-7 /+7$ event window CAR as a dependent variable. We include several control variables, namely daily 5 years CDS, daily iShares MSCI Turkey ETF, and daily Dollar-TRY exchange rate. CDS is used to control the macro risk of an economy, iShares MSCI Turkey ETF is used for a benchmark, and Dollar-TRY is used to control the return relative to the exchange rate fluctuations (During our sample period exchange rate increased approximately 15 percent). We use size, liquidity, volatility, and Google trend proxies along with the control variables. 
Haykır, Ö., \& Öztürk-Çetenak, Ö. (2022). Monetary policy application and stock market reaction during Covid-19 Pandemic: Evidence from Turkey. Ömer Halisdemir Üniversitesi İktisadi ve İdari Bilimler Fakültesi Dergisi, 15(1), 149-164.

Table 4: Average cumulative abnormal returns based on firm characteristics and Google trend sorted portfolios

\begin{tabular}{|c|c|c|c|c|c|c|c|c|c|c|c|c|c|c|c|}
\hline \multicolumn{6}{|c|}{ Size } & \multicolumn{2}{|c|}{ Liquidity } & \multicolumn{6}{|c|}{ Volatility } & \multicolumn{2}{|c|}{ Google Trend } \\
\hline Window & $-2 /+2$ & $-5 /+5$ & $-7 /+7$ & & $-2 /+2$ & $-5 /+5$ & $-7 /+7$ & & $-2 /+2$ & $-5 /+5$ & $-7 /+7$ & & $-2 /+2$ & $-5 /+5$ & $-7 /+7$ \\
\hline \multicolumn{16}{|c|}{ PANEL A: WHO Pandemic Announcement (11 March 2020) } \\
\hline Largest & $\begin{array}{l}-0.082^{*} \\
(0.056)\end{array}$ & $\begin{array}{c}-0.191 * * * * \\
(0.000)\end{array}$ & $\begin{array}{c}-0.217 * * * \\
(0.000)\end{array}$ & Liquid & $\begin{array}{c}-0.086^{* *} \\
(0.045)\end{array}$ & $\begin{array}{c}-0.164 * * \\
(0.000)\end{array}$ & $\begin{array}{c}-0.182 * * * \\
(0.000)\end{array}$ & Lowest & $\begin{array}{c}-0.083 * * \\
(0.023)\end{array}$ & $\begin{array}{c}-0.169 * * * \\
(0.000)\end{array}$ & $\begin{array}{c}-0.194 * * * \\
(0.000)\end{array}$ & High Trend & $\begin{array}{l}-0.146^{*} \\
(0.053)\end{array}$ & $\begin{array}{c}-0.298 * * * * \\
(0.000)\end{array}$ & $\begin{array}{c}-0.347 * * * * \\
(0.000)\end{array}$ \\
\hline Smallest & $\begin{array}{c}-0.223 * * \\
(0.033)\end{array}$ & $\begin{array}{c}-0.387 * * * * \\
(0.000)\end{array}$ & $\begin{array}{c}-0.436 * * * * \\
(0.000)\end{array}$ & Illiquid & $\begin{array}{c}-0.201 * * \\
(0.026)\end{array}$ & $\begin{array}{c}-0.291 * * * \\
(0.000)\end{array}$ & $\begin{array}{c}-0.301 * * * * \\
(0.000)\end{array}$ & Highest & $\begin{array}{c}-0.231 * * \\
(0.037)\end{array}$ & $\begin{array}{c}-0.399 * * * \\
(0.000)\end{array}$ & $\begin{array}{c}-0.449 * * * \\
(0.000)\end{array}$ & Low Trend & $\begin{array}{c}-0.168 * * \\
(0.035)\end{array}$ & $\begin{array}{c}-0.315 * * * \\
(0.000)\end{array}$ & $\begin{array}{c}-0.359 * * * \\
(0.000)\end{array}$ \\
\hline \multicolumn{16}{|c|}{ PANEL B: First Decline on Interest Rate (17 March 2020) } \\
\hline Largest & $\begin{array}{l}-0.087 \\
(0.177)\end{array}$ & $\begin{array}{c}-0.111 * * * \\
(0.004)\end{array}$ & $\begin{array}{c}-0.124 * * * * \\
(0.002)\end{array}$ & Liquid & $\begin{array}{l}-0.045 \\
(0.284)\end{array}$ & $\begin{array}{c}-0.079 * * \\
(0.011)\end{array}$ & $\begin{array}{c}-0.099 * * * \\
(0.002)\end{array}$ & Lowest & $\begin{array}{l}-0.079 \\
(0.169)\end{array}$ & $\begin{array}{c}-0.114 * * * \\
(0.001)\end{array}$ & $\begin{array}{c}-0.132 * * * \\
(0.000)\end{array}$ & High Trend & $\begin{array}{l}-0.122 \\
(0.105)\end{array}$ & $\begin{array}{c}-0.151 * * * * \\
(0.004)\end{array}$ & $\begin{array}{c}-0.166 * * * * \\
(0.007)\end{array}$ \\
\hline Smallest & $\begin{array}{c}-0.143^{*} \\
(0.096) \\
\end{array}$ & $\begin{array}{c}-0.210^{* * * *} \\
(0.003) \\
\end{array}$ & $\begin{array}{c}-0.249 * * * \\
(0.002) \\
\end{array}$ & Illiquid & $\begin{array}{c}-0.129^{*} \\
(0.085) \\
\end{array}$ & $\begin{array}{c}-0.162 * * * \\
(0.008) \\
\end{array}$ & $\begin{array}{c}-0.176^{* * * *} \\
(0.003) \\
\end{array}$ & Highest & $\begin{array}{c}-0.167 * \\
(0.077) \\
\end{array}$ & $\begin{array}{c}-0.240 * * * \\
(0.003) \\
\end{array}$ & $\begin{array}{c}-0.283^{* * *} * \\
(0.001) \\
\end{array}$ & Low Trend & $\begin{array}{c}-0.118 \\
(0.132) \\
\end{array}$ & $\begin{array}{c}-0.175^{* * * *} \\
(0.003) \\
\end{array}$ & $\begin{array}{c}-0.209^{* * *} \\
(0.001) \\
\end{array}$ \\
\hline \multicolumn{16}{|c|}{ PANEL C: Second Decline on Interest Rate (24 April 2020) } \\
\hline Largest & $\begin{array}{l}0.026^{* *} \\
(0.042)\end{array}$ & $\begin{array}{l}0.016 * * \\
(0.041)\end{array}$ & $\begin{array}{c}0.007 \\
(0.351)\end{array}$ & Liquid & $\begin{array}{l}0.014 * * \\
(0.014)\end{array}$ & $\begin{array}{c}0.011^{* * * *} \\
(0.002)\end{array}$ & $\begin{array}{c}0.009^{* * *} \\
(0.001)\end{array}$ & Lowest & $\begin{array}{c}0.022 * * * \\
(0.006)\end{array}$ & $\begin{array}{c}0.022^{* * * *} \\
(0.000)\end{array}$ & $\begin{array}{c}0.019^{* * *} \\
(0.002)\end{array}$ & High Trend & $\begin{array}{l}0.068^{* *} \\
(0.044)\end{array}$ & $\begin{array}{c}0.093 * * * \\
(0.000)\end{array}$ & $\begin{array}{c}0.035^{* * *} \\
(0.000)\end{array}$ \\
\hline Smallest & $\begin{array}{c}0.038^{* * * *} \\
(0.005)\end{array}$ & $\begin{array}{c}0.041 * * * * \\
(0.008)\end{array}$ & $\begin{array}{c}0.042 * * * \\
(0.000)\end{array}$ & Illiquid & $\begin{array}{c}0.073^{* *} \\
(0.017)\end{array}$ & $\begin{array}{c}0.105 * * * \\
(0.000)\end{array}$ & $\begin{array}{c}0.124 * * * \\
(0.000)\end{array}$ & Highest & $\begin{array}{l}0.062 * * \\
(0.020)\end{array}$ & $\begin{array}{c}0.066^{* * * *} \\
(0.000)\end{array}$ & $\begin{array}{c}0.062 * * * \\
(0.000)\end{array}$ & Low Trend & $\begin{array}{c}0.037 * * * \\
(0.000)\end{array}$ & $\begin{array}{c}0.036^{* * * *} \\
(0.001)\end{array}$ & $\begin{array}{c}0.035 * * * \\
(0.000)\end{array}$ \\
\hline \multicolumn{16}{|c|}{ PANEL D: Third Decline on Interest Rate (21 May 2020) } \\
\hline Largest & $\begin{array}{c}0.009 \\
(0.381)\end{array}$ & $\begin{array}{c}0.021 * * * \\
(0.006)\end{array}$ & $\begin{array}{c}0.029 * * * \\
(0.003)\end{array}$ & Liquid & $\begin{array}{c}0.004 \\
(0.374)\end{array}$ & $\begin{array}{c}0.011 * * * \\
(0.010)\end{array}$ & $\begin{array}{c}0.014 * * * \\
(0.001)\end{array}$ & Lowest & $\begin{array}{c}0.005 \\
(0.422)\end{array}$ & $\begin{array}{l}0.012 * * \\
(0.018)\end{array}$ & $\begin{array}{c}0.018^{* * *} \\
(0.001)\end{array}$ & High Trend & $\begin{array}{c}0.012 \\
(0.354)\end{array}$ & $\begin{array}{c}0.022 * * * \\
(0.009)\end{array}$ & $\begin{array}{c}0.038^{* * *} \\
(0.001)\end{array}$ \\
\hline Smallest & $\begin{array}{l}-0.002 \\
(0.847)\end{array}$ & $\begin{array}{c}0.003 \\
(0.762)\end{array}$ & $\begin{array}{c}0.011 \\
(0.269)\end{array}$ & Illiquid & $\begin{array}{c}0.009 \\
(0.569)\end{array}$ & $\begin{array}{c}0.032^{* *} \\
(0.036)\end{array}$ & $\begin{array}{c}0.045^{* * * *} \\
(0.002)\end{array}$ & Highest & $\begin{array}{c}0.002 \\
(0.546)\end{array}$ & $\begin{array}{c}-0.016 \\
(0.200)\end{array}$ & $\begin{array}{l}-0.018 \\
(0.109)\end{array}$ & Low Trend & $\begin{array}{c}0.003 \\
(0.570)\end{array}$ & $\begin{array}{c}0.003 \\
(0.725)\end{array}$ & $\begin{array}{c}0.005 \\
(0.383)\end{array}$ \\
\hline
\end{tabular}

Notes: The table reports the average cumulative abnormal return for different event windows and different events based on different characteristic-sorted portfolios. We use size (market capitalization), liquidity (Amihud), and volatility as firm characteristics and Google trend data for investor sentiment. Google trend allows researchers to get search volume within a certain time frame with certain terms. The trend number is normalized by google and scale by 100 which is the highest number and 0 is the lowest number. For brevity, the table only presents the first and last quintile average cumulative abnormal return. The statistical significance of variables is tested using the cross-sectional t-test. P-values are in the parenthesis. *, ${ }^{* *}, * * *$ show the statistical significance at the 10,5 , and 1 percent levels, respectively. 
Haykır, Ö., \& Öztürk-Çetenak, Ö. (2022). Monetary policy application and stock market reaction during Covid-19 Pandemic: Evidence from Turkey. Ömer Halisdemir Üniversitesi İktisadi ve İdari Bilimler Fakültesi Dergisi, 15(1), $149-164$.

Table 5 reports the results of our regression analysis. Panel A and B show that the coefficients of size are positive and statistically significant. Since the CAR in the first two events is negative, the results suggest that larger firms have low negative returns than smaller firms. In the third event, size is negative and significant so that the smallest firms earn more returns around good news. Small firms are riskier and earn negative returns during bad events and earn positive returns during positive events. Liquidity proxy demonstrates similar results as size. In the first two events, liquid firms earn more return (less negative return), and the last two events increase in illiquidity leads to an increased CAR. Volatility has a similar direction as liquidity. Google trend coefficient shows that increase in google trend will increase the CAR on our event window for three out of four events.

Table 5: Regression analysis

\begin{tabular}{|c|c|c|c|c|}
\hline \multicolumn{5}{|c|}{ Dependent variable CAR $[-7 /+7]$} \\
\hline Variables & (1) & (2) & (3) & (4) \\
\hline \multicolumn{5}{|c|}{ PANEL A: WHO Pandemic Announcement (11 March 2020) } \\
\hline Size & $\begin{array}{l}0.0255^{* * *} \\
(0.000)\end{array}$ & & & \\
\hline Liquidity & & $\begin{array}{l}-0.065 \\
(0.227)\end{array}$ & & \\
\hline Volatility & & & $\begin{array}{l}-2.895^{* * *} \\
(0.000)\end{array}$ & \\
\hline Google Trend & & & & $\begin{array}{c}-0.0001 \\
(0.762)\end{array}$ \\
\hline CDS & $\begin{array}{l}-0.316^{* * *} \\
(0.000)\end{array}$ & $\begin{array}{l}-0.329 * * * \\
(0.000)\end{array}$ & $\begin{array}{l}-0.303 * * * \\
(0.000)\end{array}$ & $\begin{array}{l}-0.329 * * * \\
(0.000)\end{array}$ \\
\hline MSCI Turkey Index & $\begin{array}{l}2.274 * * * \\
(0.000)\end{array}$ & $\begin{array}{l}2.304 * * * \\
(0.000)\end{array}$ & $\begin{array}{l}2.171 * * * \\
(0.000)\end{array}$ & $\begin{array}{l}2.349 * * * \\
(0.000)\end{array}$ \\
\hline Dollar-TRY & $\begin{array}{l}6.988 * * * \\
(0.000)\end{array}$ & $\begin{array}{l}7.083 * * * \\
(0.000)\end{array}$ & $\begin{array}{l}6.864 * * * \\
(0.000)\end{array}$ & $\begin{array}{l}7.267 * * * \\
(0.000)\end{array}$ \\
\hline Constant & $\begin{array}{l}-18.624 * * * \\
(0.000)\end{array}$ & $\begin{array}{l}-18.290 * * * \\
(0.000)\end{array}$ & $\begin{array}{l}-17.520 * * * \\
(0.000)\end{array}$ & $\begin{array}{l}-18.772 * * * \\
(0.000)\end{array}$ \\
\hline R-Squared & 0.683 & 0.646 & 0.680 & 0.640 \\
\hline \multicolumn{5}{|c|}{ PANEL B: First Decline on Interest Rate (17 March 2020) } \\
\hline Size & $\begin{array}{l}0.041 * * * \\
(0.000)\end{array}$ & & & \\
\hline Liquidity & & $\begin{array}{l}-0.053 \\
(0.343)\end{array}$ & & \\
\hline Volatility & & & $\begin{array}{l}-5.087 * * * \\
(0.000)\end{array}$ & \\
\hline Google Trend & & & & $\begin{array}{l}0.001 * * * \\
(0.008)\end{array}$ \\
\hline CDS & $\begin{array}{l}-0.222 * * * \\
(0.000)\end{array}$ & $\begin{array}{l}-0.235^{* * *} \\
(0.000)\end{array}$ & $\begin{array}{l}-0.116^{* * *} \\
(0.003)\end{array}$ & $\begin{array}{l}-0.239 * * * \\
(0.000)\end{array}$ \\
\hline MSCI Turkey Index & $\begin{array}{l}1.622 * * * \\
(0.000)\end{array}$ & $\begin{array}{l}1.677 * * * \\
(0.000)\end{array}$ & $\begin{array}{l}1.686^{* * * *} \\
(0.000)\end{array}$ & $\begin{array}{l}1.685^{* * * *} \\
(0.000)\end{array}$ \\
\hline Dollar-TRY & $\begin{array}{l}3.641 * * * \\
(0.000)\end{array}$ & $\begin{array}{l}3.773 * * * \\
(0.000)\end{array}$ & $\begin{array}{l}4.120 * * * \\
(0.000)\end{array}$ & $\begin{array}{l}3.887 * * * \\
(0.000)\end{array}$ \\
\hline Constant & $\begin{array}{l}-11.399 * * * \\
(0.000)\end{array}$ & $\begin{array}{l}-10.898^{* * *} \\
(0.000)\end{array}$ & $\begin{array}{l}-12.067 * * * \\
(0.000)\end{array}$ & $\begin{array}{l}-11.116^{* * *} \\
(0.000)\end{array}$ \\
\hline R-Squared & 0.494 & 0.383 & 0.514 & 0.372 \\
\hline \multicolumn{5}{|c|}{ PANEL C: Second Decline on Interest Rate (24 April 2020) } \\
\hline Size & $\begin{array}{l}-0.003 * * * \\
(0.002)\end{array}$ & & & \\
\hline Liquidity & & $\begin{array}{l}2.144 * * * \\
(0.001)\end{array}$ & & \\
\hline Volatility & & & $\begin{array}{l}0.905 * * * \\
(0.000)\end{array}$ & \\
\hline Google Trend & & & & $\begin{array}{l}0.002 * * * \\
(0.000)\end{array}$ \\
\hline CDS & $\begin{array}{l}-0.059 \\
(0.240)\end{array}$ & $\begin{array}{l}-0.033 \\
(0.523)\end{array}$ & $\begin{array}{l}-0.099^{*} \\
(0.059)\end{array}$ & $\begin{array}{l}-0.036 \\
(0.458)\end{array}$ \\
\hline
\end{tabular}


Haykır, Ö., \& Öztürk-Çetenak, Ö. (2022). Monetary policy application and stock market reaction during Covid-19 Pandemic: Evidence from Turkey. Ömer Halisdemir Üniversitesi İktisadi ve İdari Bilimler Fakültesi Dergisi, 15(1), $149-164$.

\begin{tabular}{|c|c|c|c|c|}
\hline MSCI Turkey Index & $\begin{array}{l}0.844 * * * \\
(0.000)\end{array}$ & $\begin{array}{l}0.885 * * * \\
(0.000)\end{array}$ & $\begin{array}{l}0.948 * * * \\
(0.000)\end{array}$ & $\begin{array}{l}0.790 * * * \\
(0.000)\end{array}$ \\
\hline Dollar-TRY & $\begin{array}{l}1.885 * * * \\
(0.000)\end{array}$ & $\begin{array}{l}1.944 * * * \\
(0.000)\end{array}$ & $\begin{array}{l}2.334 * * * \\
(0.000)\end{array}$ & $\begin{array}{l}1.771 * * * \\
(0.000)\end{array}$ \\
\hline Constant & $\begin{array}{l}-5.702 * * * \\
(0.000)\end{array}$ & $\begin{array}{l}-6.167 * * * \\
(0.000)\end{array}$ & $\begin{array}{l}-6.731 * * * \\
(0.000)\end{array}$ & $\begin{array}{l}-5.539 * * * \\
(0.000)\end{array}$ \\
\hline R-Squared & 0.030 & 0.042 & 0.038 & 0.071 \\
\hline \multicolumn{5}{|c|}{ PANEL D: Third Decline on Interest Rate (21 May 2020) } \\
\hline Size & $\begin{array}{l}0.0001 \\
(0.852)\end{array}$ & & & \\
\hline Liquidity & & $\begin{array}{l}4.598 * * * \\
(0.000)\end{array}$ & & \\
\hline Volatility & & & $\begin{array}{l}0.064 \\
(0.779)\end{array}$ & \\
\hline Google Trend & & & & $\begin{array}{l}0.0003 * * * \\
(0.004)\end{array}$ \\
\hline CDS & $\begin{array}{l}0.014 \\
(0.814)\end{array}$ & $\begin{array}{l}0.026 \\
(0.657)\end{array}$ & $\begin{array}{l}0.014 \\
(0.230)\end{array}$ & $\begin{array}{l}0.016 \\
(0.786)\end{array}$ \\
\hline MSCI Turkey Index & $\begin{array}{l}0.022 \\
(0.844)\end{array}$ & $\begin{array}{l}0.025 \\
(0.826)\end{array}$ & $\begin{array}{l}0.023 \\
(0.841)\end{array}$ & $\begin{array}{l}0.018 \\
(0.877)\end{array}$ \\
\hline Dollar-TRY & $\begin{array}{l}-0.876^{* *} \\
(0.012)\end{array}$ & $\begin{array}{l}-1.002 * * * \\
(0.004)\end{array}$ & $\begin{array}{l}-0.879 * * \\
(0.012)\end{array}$ & $\begin{array}{l}-0.904 * * \\
(0.010)\end{array}$ \\
\hline Constant & $\begin{array}{l}1.566 \\
(0.115)\end{array}$ & $\begin{array}{l}1.719^{*} \\
(0.079)\end{array}$ & $\begin{array}{l}1.571 \\
(0.114)\end{array}$ & $\begin{array}{l}1.619 \\
(0.103)\end{array}$ \\
\hline R-Squared & 0.017 & 0.039 & 0.017 & 0.021 \\
\hline
\end{tabular}

Notes: Table presents the regression results where the $[-7 /+7]$ days average cumulative abnormal return as dependent variable and size, liquidity, volatility, Google trend, and 5 years CDS, iShares MSCI Turkey ETF, and Dollar-TRY exchange rate are independent variables. The regression model is as follows: $C A R_{t-7, t+7}=\beta_{0}+\beta_{1}$ Size $+\beta_{2} C D S+\beta_{3}$ MSCI Turkey Index $+\beta_{4}$ Dollar_TRY $+\varepsilon_{i}$. In the second column, we replace size with liquidity and in the third column with volatility, and in the last column with Google trend. We use robust standard errors and $\mathrm{p}$-values are in the parenthesis. ${ }^{*},{ }^{* *},{ }^{* *}$ show the statistical significance at the 10,5 , and 1 percent levels, respectively.

\section{CONCLUSION}

This study explains the stock market reaction to the COVID-19 pandemic announcement and three monetary policy application changes after that in the Turkish stock market. Countries have responded differently against the COVID-19 pandemic to slow down the meltdown in economies. One of the responses is to use monetary policy tools and lower the interest rate after the pandemic announcement. When the uncertainty increases, economic growth is slowing. As a response, the Central Banks cut the target interest rate to stimulate financial activity. Lowering interest rates generally encourages investing and leads to higher stock prices.

The results of the study show that stock return and liquidity decrease after the pandemic announcement. The stock return is declined around 16 percent and liquidity decreases around five percent after the announcement of the pandemic. However, the stock return and liquidity increase especially after the second and third reduction of interest rate. Furthermore, results show that smaller, illiquid, and less Google-searched firms are affected more by the pandemic announcement, and they have a strong response to positive events (second and third reduction of interest rate).

Overall, our findings suggest that reducing the interest rate helps to recover the return and liquidity of stocks, but the results should be interpreted carefully since the low-interest rate is not always desirable for the economy since it causes inflation. The analysis can be expanded by analyzing the stock market reaction to monetary policy application change around the world. 
Haykır, Ö., \& Öztürk-Çetenak, Ö. (2022). Monetary policy application and stock market reaction during Covid-19

Pandemic: Evidence from Turkey. Ömer Halisdemir Üniversitesi İktisadi ve İdari Bilimler Fakültesi Dergisi, 15(1), $149-164$.

\section{REFERENCES}

Ahmar, A.S., \& del Val, E.B. (2020). SutteARIMA: Short-term forecasting method, a case: Covid-19 and stock market in Spain. Science of the Total Environment, 729, 138883.

Al-Awadhi, A.M., Al-Saifi, K., Al-Awadhi, A., \& Alhamadi, S. (2020). Death and contagious infectious diseases: Impact of the COVID-19 virus on stock market returns. Journal of Behavioral and Experimental Finance, $27,100326$.

Alber, N. (2020). The effect of coronavirus spread on stock markets. The case of the worst 6 countries, Available at http://ssrn.com/abstract $=3578080$.

Alexander, W.E., Balino, T.J.T., \& Enoch, C. (1995). The Adoption of Indirect Instruments of Monetary Policy. IMF Working Paper, $126 . \quad$ Available at https://www.imf.org/external/pubs/ft/fandd/1996/03/pdf/alexande.pdf.

Amihud, Y. (2002). Illiquidity and stock returns: Cross-section and time-series effects. Journal of Financial Markets, 5, 531-556.

Ashraf, B. N. (2020). Stock markets' reaction to COVID-19: cases or fatalities?. Research in International Business and Finance, 54, 101249.

Bai, L., Wei, Y., Wei, G., Li, X., \& Zhang, S. (2021). Infectious disease pandemic and permanent volatility of international stock markets: A long-term perspective. Finance Research Letters, 40, 101709.

Baldwin, R., \& Mauro, B. W. (2020). Mitigating the COVID economic crisis: act fast and do whatever it takes. A VoxEU.org Book, CEPR Press.

Baker, S. R., Bloom, N., Davis, S. J., Kost, K., Sammon, M., \& Viratyosin, T. (2020). The unprecedented stock market reaction to COVID-19. The Review of Asset Pricing Studies, 10 (4), 742-758.

Bank, M., Larch, M., \& Peter, G. (2011). Google search volume and its influence on liquidity and returns of German stocks. Financial Markets and Portfolio Management, Vol. 25 No. 3, pp. 239-264.

Bekaert G., \& Harvey C. R. (1995). Emerging Equity Market Volatility. National Bureau of Economic Research, Working Paper, No. 5307.

Bernanke, B., \& Blinder, A. (1990). The federal funds rate and the channels of monetary transmission. National Bureau of Economic Research, Working Paper, No. w3487.

Brown, S., \& Warner, J. (1980). Measuring security price performance. Journal of Financial Economics, 8, 205258.

Brown, S., \& Warner, J. (1985). Using Daily Stock Returns: The Case of Event Studies. Journal of Financial Economics, 14, 3-31.

Carlsson-Szlezak, P., Reeves, M., \& Swartz, P. (2020). What coronavirus could mean for the global economy. Harvard Business Review, 1-10.

Central Securities Depository of the Turkish Capital Markets (2020). Retrieved from: https://www.mkk.com.tr/trtr/haberler/Sayfalar/Pay-Piyasasi-Yatirimci-Sayisi-2-Milyonu-Asti.aspx.

Conrad, J. (1989). The Price Effect of Option Introduction. Journal of Finance, 44 (1989), 487-499.

Contessi, S., \& De Pace, P. (2021). The international spread of COVID-19 stock market collapses. Finance Research Letters, 101894.

Cox, J. (2020). FED pumps in more than $\$ 1$ trillion in dramatic ramping up of market intervention amid coronavirus meltdowns. CNBC (12 March 2020). Retrieved from: https://www.cnbc.com/2020/03/12/fedto-pump-more-than-500-billion-into-short-term-bank-funding-expand-types-of-security-purchases.html.

Da, Z., Engelberg, J., \& Gao, P. (2011). In search of attention. The Journal of Finance, 66, 1461-1499.

Detemple, J., \& Jorion, P. (1990). Option Listing and Stock Returns. Journal of Banking and Finance, 14 (1990), 781-802. 
Haykır, Ö., \& Öztürk-Çetenak, Ö. (2022). Monetary policy application and stock market reaction during Covid-19

Pandemic: Evidence from Turkey. Ömer Halisdemir Üniversitesi İktisadi ve İdari Bilimler Fakültesi Dergisi, 15(1), $149-164$.

Dooley, M., \& Hutchison, M. (2009). Transmission of the US Subprime Crisis to Emerging Markets: Evidence on the Decoupling-Recoupling Hypothesis. Journal of International Money and Finance, 28 (8), 13311349.

Elgin, C., Basbug, G., \& Yalaman, A. (2020). Economic policy responses to a pandemic: developing the COVID19 economic stimulus index. Covid Economics: Vetted and Real Time papers, 3, 40-54.

Engelhardt, N., Krause, M., Neukirchen, D., \& Posch, P. N. (2021). Trust and stock market volatility during the COVID-19 crisis. Finance Research Letters, 38, 101873.

Fernandez, N. (2020). Economic effects of coronavirus outbreak (Covid-19) on the world economy. Available at http://ssrn.com/abstract=3557504.

Google Trends (2020). Google Data. Retrieved from: https://trends.google.com.tr/trends/?geo=TR.

Gormsen, N. J., \& Koijen, R. S. (2020). Coronavirus: impact on stock prices and growth expectations. University of Chicago, Becker Friedman Institute for Economics Working Paper.

Gumus, G. K. (2010). Menkul Kıymet Piyasalarında Yabancı Yatırımcıların Etkisi: İstanbul Menkul Kıymetler Borsası Örneği. IMKB Dergisi, 11, 61-96.

Han, L., Xu, Y., \& Yin, L. (2018). Does investor attention matter? The attention-return relationship in FX markets. Economic Modelling, 68:660-664.

Herwany, A., Satyakti, Y., \& Wardhana, W. (2017). The impact of monetary policy on stock market liquidity and the business cycle in indonesia. Available at https://papers.ssrn.com/sol3/papers.cfm?abstract_id=3030518.

Hibbert, A.M., \& Pavlova, I. (2017). The drivers of sovereign CDS spread changes: local versus global factors. Financial Review, 52, 435-457.

Huang, M., Rojas, R., \& Convery, P., D. (2020). Forecasting stock market movements using Google Trend Searches. Empirical Economics, 59, 2821-2839.

Investing (2020). Investing Data. Investing.com, Cyprus.

Jain, P. C. (1987). The Effect on Stock Price of Inclusion in or Exclusion from the S\&P 500. Financial Analyst Journal, 43, 58-65.

Kandil Göker, İ., Eren, B., \& Karaca, S. (2020). The Impact of the COVID-19 (Coronavirus) on The Borsa Istanbul Sector Index Returns: An Event Study. Gaziantep University Journal of Social Sciences, 19, 1441.

Kartal, M. T. (2020). The behavior of sovereign credit default swaps (CDS) spread evidence from turkey with the effect of covid-19 pandemic. Available at https://ssrn.com/abstract=3642652.

Kasch, M., \& Sarkar, A. (2011). Is there an S\&P 500 Index Effect, Federal Reserve Bank of New York Staff Report, 484.

Khan, K., Zhao, H., Zhang, H., Yang, H., Shah, M., H., \& Jahanger, A. (2020). The Impact of COVID-19 Pandemic on Stock Markets: An Empirical Analysis of World Major Stock Indices. Journal of Asian Finance, Economic, and Business, 7 (7), 463-474.

Nicola, M., Alsafi, Z., Sohrabi, C., Kerwan, A., Al-Jabir, A., Iosifidis, C., \& Agha, R. (2020). The socioeconomic implications of the coronavirus and COVID-19 pandemic: a review. International Journal of Surgery, 78, 185-193.

Rahman, Md., L., Amin, A., \& Mamun, M. A. A. (2020). The COVID-19 outbreak and stock market reactions: Evidence from Australia. Finance Research Letters, 101832.

Sansa, N.A. (2020). The impact of Covid-19 on the financial markets. Evidence from China and USA. Available at http://ssrn.com/abstract=3562530.

Scharler, J. (2008). Do bank-based financial systems reduce macroeconomic volatility by smoothing interest rates?. Journal of Macroeconomics, 30 (3), 1207-1221.

Schweitzer, R. (1989). How Do Stock Returns React to Special Events?. Business Review, issue July, 17-29. 
Haykır, Ö., \& Öztürk-Çetenak, Ö. (2022). Monetary policy application and stock market reaction during Covid-19 Pandemic: Evidence from Turkey. Ömer Halisdemir Üniversitesi İktisadi ve İdari Bilimler Fakültesi Dergisi, 15(1), $149-164$.

Senol, Z., \& Zeren, F. (2020). Coronavirus (COVID-19) and stock markets. The effects of pandemic on the global economy. Eurasian Journal of Researches in Social and Economics, 7(4), 1-16.

Shleifer, A. (1986). Do Demand Curves for Stocks Slope Down?. The Journal of Finance, 41, 579- 590.

Sorescu, S. (2000). The Effect of Options on Stock Prices: 1973-1995. The Journal of Finance, 55, 487-514.

Topcu, M., \& Gulal, O. S. (2020). The impact of COVID-19 on emerging stock markets. Finance Research Letters, 36, 101691.

Vlastakis, N., \& Markellos, R. N. (2012). Information demand and stock market volatility. Journal of Banking and Finance, Vol. 36 No. 6, pp. 1808-1821.

World Health Organization (2020). WHO Director-General's opening remarks at the media briefing on COVID19. Retrieved from: https://www.who.int/docs/default-source/coronaviruse/transcripts/who-audioemergencies-coronavirus-press conference-full-and-final-11 mar2020.pdf?sfvrsn=cb432bb3_2.

Worlddometer (2020). Worlddometer statistics. Retrieved from: https://www.worldometers.info/coronavirus/.

Xinhua, H. (2020). China financial markets remains stable amid Covid-19 impact. Available at https://www.chinadailyhk.com/article/125145.

Yan, C. (2020). COVID-19 Outbreak and Stock Prices: Evidence from China. Available at http://ssrn.com/abstract $=3574374$.

Yang, L., Yang, L., \& Hamori, S. (2018). Determinants of Dependence Structures of Sovereign Credit Default Swap Spreads between G7 and BRICS Countries. International Review of Financial Analysis, 59, 19-34.

Zeren, F., \& Hizarci, A. E. (2020). The impact of Covid-19 coronavirus on stock markets. Evidence from selected countries. Muhasebe ve Finans Incelemeleri Dergisi, 3(1), 78-84.

Zhang, D., Hu, M., \& Ji, Q. (2020). Financial markets under the global pandemic of COVID-19. Finance Research Letter, 101528. 
Haykır, Ö., \& Öztürk-Çetenak, Ö. (2022). Monetary policy application and stock market reaction during Covid-19 Pandemic: Evidence from Turkey. Ömer Halisdemir Üniversitesi İktisadi ve İdari Bilimler Fakültesi Dergisi, 15(1), $149-164$.

Etik Beyanı : Bu çalışmanın tüm hazırlanma süreçlerinde etik kurallara uyulduğunu yazarlar beyan eder. Aksi bir durumun tespiti halinde ÖHÜIİBF Dergisinin hiçbir sorumluluğu olmayıp, tüm sorumluluk çalışmanın yazar(lar)ina aittir.

Yazar Katkıları $\quad$ : "Monetary Policy Application and Stock Market Reaction During Covid-19 Pandemic: Evidence from Turkey” adlı çalışmada 1. yazarın katkı oranı: \%50, 2. yazarın katkı oranı: \%50

Çıkar Beyanı : : Yazarlar arasında çıkar çatışması yoktur.

Ethics Statement : The authors declare that ethical rules are followed in all preparation processes of this study. In case of detection of a contrary situation, ÖHÜIIBF Journal has no responsibility and all responsibility belongs to the authors of the study.

Author Contributions : In this study 1st author's contribution rate: $50 \%$, 2nd author's contribution rate: $50 \%$ 